\section{DIY microarrayers promise DNA chips with everything}

\section{San Francisco}

DNA chips are one of the most exciting, powerful - and expensive - genome technologies. A group of Californian scientists has now developed a do-it-yourself kit, available on the web, designed to bring them within the reach of laboratories on tight budgets.

DNA chips, or microarrays, consist of wafers, usually made of glass, etched with hundreds of thousands of microscopic wells. Each well contains a short stretch of DNA, which bonds with any matching strands in a sample, the matches being identified using fluorescent tags. This high-throughput screen is ideal for detecting specific genes, and has applications from evolutionary biology to the diagnosis of disease.

Two years ago, a group of scientists concerned about the cost of microarray chips and chip-making equipment set up a website with instructions on how to build a microarray system for making custom chips (http:// cmgm.stanford.edu/pbrown/mguide/). The group includes Joseph DeRisi of the University ofCalifornia at San Francisco, Mike Eisen of Lawrence Berkeley National Laboratory, and Pat Brown, Paul Spellman and Max Diehn, all of Stanford University. DeRisi is a former postdoc in Brown's laboratory, where the system originated.

A 'freeware' database designed for microarray data is the team's latest offering. The software, which was posted to the group's new website on 1 January, allows users to store, sort and analyse genetic data (see http://www.microarrays.org)

Janet Hager, a cell biologist at Yale University, says that comparable commercial software would cost up to $\$ 200,000$.

The "Mguide", as the "Brown lab's complete guide to microarraying" is called, leads a researcher through buying, assembling and operating a microarray chip maker. The main equipment is a computer-controlled robotic arm - originally designed for the semiconductor industry - that drops DNA specimens onto chips. Chips are then analysed using a scanner, a separate piece of equipment that can be made or bought.

Using the website, a researcher can build a microarrayer for about $\$ 30,000$ - half the price of a commercial machine, whose costs have themselves dropped substantially in recent years. It costs about $\$ 30,000$ to buy a scanner and slightly less to build one.

Kenneth Burtis, a molecular biologist at the University of California, Davis, who has built a microarray from Mguide, says it helps to be a "tinkering" person. DeRisi, a fellow in biochemistry and biophysics, says: "A 14-

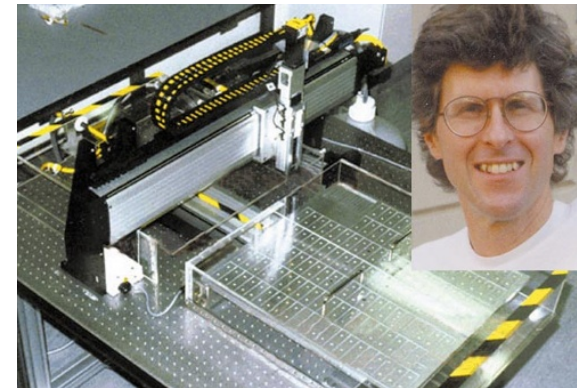

Home cooking: building your own microarrayer costs half as much as buying one. Inset: DeRisi

year-old could build one in about ten hours." Home-made microarrayers are in laboratories at institutions such as Yale University, Uppsala University in Sweden and the Institute of Food Research in Norwich, England.

Scientists from these institutions took part in a microarray course last November at Cold Spring Harbor Laboratory in New York, where Brown, DeRisi and colleagues provided intense instruction. The 16 participants — out of 125 applicants — made four microarrays and learned how to use them.

Cold Spring Harbor is planning a second course in June. This is planned to concentrate on the use of microarrays. Since the first course, the Mguide website has been upgraded with a system that greatly expands the microarrays' production capability.

Hager took a microarrayer back to Yale, where scientists from 25 research projects have teamed up to use the equipment, funded by a grant from the National Cancer Institute. It "was a challenge to build, but rewarding," says Hager. "The challenge for the future will be bioinformatics, interpreting the vast amount of data" from the microarrays.

Burtis says that the group deserves praise for bucking what he describes as a trend towards commercialization in bioinformatics, by sharing its knowledge without seeking to make a profit.

Affymetrix, a company based in Santa Clara, California, and the leader in DNAchip technology, sells its chips for $\$ 100$ to $\$ 2,000$ each. Dave Crawford, marketing director at Affymetrix, says the scientists are "providing a valuable service to the academic community" and have "contributed a tremendous amount" to the microarray market. Affymetrix will introduce a range of cheaper chip products targeted at academic researchers later this year, he says.

Agilent Technologies, Motorola, Corning and other companies are following Affymetrix into the microarray market, and competition is expected to force down prices.

Rex Dalton

๙ 02000 Macmillan Magazines Ltd

\section{Australian university chiefs attack plans for research funding}

Sydney

The Australian Vice-Chancellors' Committee has criticized a white paper released by the education minister David Kemp as being "flawed" by the government's refusal to accept that Australia's research base needs major additional investment.

Kemp says that the white paper, which seeks to tie research to its commercial potential, is intended to make Australia competitive in "the global knowledge economy". Kemp also confirmed legislation to establish the grant-giving Australian Research Council (ARC) as "an independent body with broader membership and a more strategic role”.

Criticism has focused on the government's refusal to restore cuts to research budgets. Deryck Schreuder, the acting president of the vice-chancellor's committee, says that the "key contention" that Australian funding is comparable to that of other countries in the Organisation for Economic Cooperation and Development is based on outdated figures and shows a complacency that has left university funding "critical".

Kemp has jettisoned six of the more contentious aspects of his proposals (see Nature 402, 113; 1999), notably a voucher scheme for postgraduate students, a shorter completion time for graduate degrees, and the abolition of a blockgrants programme for research infrastructure.

The Federation of Australian Scientific and Technological Societies is also challenging the government's statistics. Its new president, Sue Serjeantson, wants an independent audit of public spending on research "that permits valid international comparisons". Serjeantson claims the government has inflated its figures by including grants for the humanities, economics and social sciences.

Deane Terrell, vice-chancellor of the Australian National University, welcomed "the emphasis on performance-based funding for research training and infrastructure," but says that the problem of more money "remains to be addressed".

The Australian Academy of Science welcomed the strengthening of the ARC, but attacked the use of "simplistic formulae" to allocate money. It advocated an assessment exercise that would reward excellence.

Peter Pockley 